International Journal of Library \& Information Science (IJLIS)

Volume 8, Issue 1, January-February 2019, pp. 1-14, Article ID: IJLIS_08_01_001

Available online at

http://iaeme.com/Home/issue/IJLIS?Volume $=8 \&$ Issue $=1$

Journal Impact Factor (2016): 8.2651 (Calculated by GISI) www.jifactor.com

ISSN Print: 2277-3533 and ISSN Online: 2277-3584

(C) IAEME Publication

\title{
INFORMATION LITERACY COMPETENCE AND SKILLS AMONG FACULTY MEMBERS OF BLDE AND SECAB ENGINEERING COLLEGES IN VIJAYAPURA
}

Fairojakhatun Pathan

Research scholar, Department of Library and Information Science Akkamahadevi Women's University Vijayapur,Karnataka, India.

\section{Gavisiddappa Anandhalli}

Pofessor and Chairman, Department of Library and Information Science Akkamahadevi Women's University Vijayapur,Karnataka, India

\begin{abstract}
The present study explores the Information literacy competencies and skills among the faculty members of engineering colleges in vijayapura. A survey method of research was used for the present study where in structured questionnaire was designed for the purpose of data collection. 150 questionnaires were distributed among the faculty of engineering colleges of BLDE and SECAB faculty members. The present paper aims to highlight the knowledge about skills of the information literacy that allows faculty to searching and locating and evaluation, and uses the information .The study found that majority of the faculty have better knowledge and skills about uses different types of sources and resources and different kind of tools and services respects in their fields
\end{abstract}

Keywords: Information literacy, searching skills, sources of information, engineering faculty

Cite this Article: Fairojakhatun Pathan and Gavisiddappa Anandhalli, Information Literacy Competence and Skills among Faculty Members of Blde and Secab Engineering Colleges in Vijayapura, International Journal of Library \& Information Science, 8(1), 2019, pp. 1-14.

http://iaeme.com/Home/issue/IJLIS?Volume $=8 \&$ Issue $=1$

\section{INTRODUCTION}

The term of information literacy is very important for, technical education or engineering education because engineering science or technical courses or fields provide technical education has particular challenges in identifying, evaluating and using information from diverse sources and formats such as technical standards, journal articles and patent. The term 
Information literacy is defined as the "set of abilities requiring individuals to recognize when information is needed and have the ability to locate evaluate and use effectively the needed information" (ALA: 1989). A similar understanding of information literacy is assumed by Andretti (2005: 15) who defines information literacy as the ability to identify the need for information; to know the importance of accurate and authentic information; to develop search strategies to assist in finding information; to source information; to evaluate information; and, to use and organize information effectively (MousinOmarsaib 2015).

"Information literacy in science, engineering, and technology disciplines is defined as a set of abilities to identify the need for information, procure the information, evaluate the information and subsequently revise the strategy for obtaining the information, to use the information and to use it in an ethical and legal manner, and to engage in lifelong learning. Information literacy competency is highly important for students in science and engineering/technology disciplines who must access a wide variety of information sources and formats that carry the body of knowledge in their fields. These disciplines are rapidly changing and it is vital to the practicing scientist and engineer that they know how to keep up with new developments and new sources of experimental/research data. Science, engineering, and technology disciplines require that students demonstrate competency not only in written assignments and research papers but also in unique areas such as experimentation, laboratory research, and mechanical drawing).

*Information literacy and higher engineering education. Developing lifelong learners is central to the mission of higher education institution. Ensuring that individuals have the intellectual abilities of reasoning and critical thinking, and by helping them to construct a framework for learning how to learn, colleges and universities provide the foundation for continued growth thoughttheir careers, as well as in their roles as informed citizens and members of communities. Information literacy is key component of, and contributor to, lifelong learning. Information literacy is increasingly important in contemporary environment of rapid technological changes and proliferating information resources.("transilvania" university library along the search and write tutorial).

\section{REVIEW OF LITERATURE}

Rosenzweig and Gardner (1994) reported on their survey in Chemical Engineering Progress that, "chemical engineers today spend a considerable amount of time retrieving and using information on a wide variety of topics..." but, "depended on personal collections and other engineers for their information, and were not making good use of the growing number of electronic options. More than half the survey respondents attributed this to their inability to find and use appropriate information".

Kristin M. Klucevsek \& Allison B. Brungard (2016). For undergraduate students to achieve science literacy, they must first develop information literacy skills. These skills align with Information Literacy Standards and include determining appropriate databases, distinguishing among resource types, and citing resources ethically. To effectively improve information literacy and science literacy, we must identify how students interact with authentic scientific texts. In this case study, we addressed this aim by embedding a science librarian into a science writing course, where students wrote a literature review on a research topic of their choice. Library instruction was further integrated through the use of an online guide and outside assistance. To evaluate the evolution of information literacy in our students and provide evidence of student practices, we used tasks scaffold writing assessments, a reflection, and surveys. We found that students improved their ability and confidence in finding research articles using discipline-specific databases as well as their ability to distinguish primary from secondary research articles. We also identified ways students 
Information Literacy Competence and Skills among Faculty Members of Blde and Secab Engineering Colleges in Vijayapura

improperly used and cited resources in their writing assignments. While our results reveal a better understanding of how students find and approach scientific research articles, additional research is needed to develop effective strategies to improve long-term information literacy in the sciences.

\section{OBJECTIVE OF THE STUDY}

The main objectives of study are:

1. To know the level of knowledge of information literacy skill among faculty members of BLDE, SECAB Engineering colleges.

2. To understand the skill level in identifying types of information sources by the faculty members of engineering colleges.

3. To identify the different information search technique used by the faculty members of engineering colleges.

4. To find out how the faculty members are locate and access information in libraries of engineering colleges.

5. To find out the computer and ICT literacy skills among the faculty members of engineering colleges.

6. To know how the selected information is evaluated by the faculty members of engineering colleges.

\section{NEED FOR THE STUDY}

The study is undertaken to investigate the level of competency and skills among the faculty members of engineering colleges of BLDE and SECAB .The study population is basically involved in teaching, research and knowledge extension. The Faculty of engineering college require constantly update their existing knowledge in their field. Information available in different form and structure as there is enormous information available in the from all the resources and remote corner of the world. Thus present study will be carried out to find out extent information literacy competency skill among the faculty of engineering colleges in vijayapura.

\section{SCOPE AND LIMITATION OF THE STUDY}

The present study is explorative nature based on the primary data collected from study population BLDE and SECAB engineering colleges in vijayapura. The study will conducted with the intention to understand the information literacy skills and competencies among the faculties and confined only B.E, M.E and Ph.D. in the Civil, Mechanical, Electronic and Electrical, Computer science branches have taken.

\section{METHODOLOGY}

This study covers the engineering colleges of BLDE and SECAB. The survey method of research was used. Further structured questionnaire was used as data collection tool for collecting required information from the study population. Questionnaire was designed according to the objectives and available literature on the topic information literacy competencies and skills. Further appropriate sampling technique was adopted for selection of the sample. Later structure questionnaire was distributed among the faculty members of engineering colleges of BLDE; SECAB.The data so collected was analyzed, tabulated and interpreted in the fallowing section. 


\section{ANALYSIS AND INTERPRETATION OF THE DATA}

Information literacy competencies and skill are important for technical education or engineering education to increase the familiarity of topics identifying key concept recognize and update exist knowledge a identifies value of difference of potential resources in various formats in their discipline.

Table 1 Gender wise distribution of the respondents

\begin{tabular}{|c|c|c|c|}
\hline SI no & Gender & Frequency & Percent (\%) \\
\hline 1 & Male & 91 & 60.7 \\
\hline 2 & Female & 59 & 39.3 \\
\hline & Total & 150 & 100.0 \\
\hline
\end{tabular}

The above table presents the gender wise distribution of the study sample, it is found that majority of the study population $91(60.7 \%)$ belong to male category. While, remaining 59 $(39.3 \%)$ of the respondent belongs to female category. It can be concluded that majority of the study sample belongs to male counterpart only.

Table-2 Age of the respondents

\begin{tabular}{|c|c|c|c|}
\hline Sl.no & $\begin{array}{c}\text { Age of the } \\
\text { respondents }\end{array}$ & Frequency & Percent (\%) \\
\hline 1 & Less than 35 age & 68 & $45.33 \%$ \\
\hline 2 & $35-45$ years & 72 & $48 \%$ \\
\hline 3 & More than 45 years & 10 & $6.66 \%$ \\
\hline & Total & 150 & 100.0 \\
\hline
\end{tabular}

Table-2 reveals about age wise distribution of the faculty members of engineering college under study. It has been observed that more than $68(45.33 \%)$ of the study sample have less than 35 years of age and remaining, $72(48 \%)$ of the respondents were in between 35-45 years of age. And only 10(6.66\%) were more than 45 years.

Table 3 Domicile wise distribution of the respondents

\begin{tabular}{|c|c|c|c|}
\hline SI no & Place & Frequency & Percent (\%) \\
\hline 1 & Rural & 22 & $14.66 \%$ \\
\hline 2 & Urban & 128 & $85.33 \%$ \\
\hline & Total & 150 & 100.0 \\
\hline
\end{tabular}

Table- 3 indicates place wise distribution of the respondents under study, greater majority of the study population $128(85.33 \%)$ belongs to urban place and while only $22(14.66 \%)$ of the study population belongs to rural area. It can be concluded that representation of the study population is less from rural area.

Table 4 Do you Visit to library?

\begin{tabular}{|c|c|c|c|}
\hline Sl no & Opinion & Frequency & Percent \\
\hline 1 & Yes & 150 & 100.0 \\
\hline 2 & No & 0 & 0 \\
\hline & Total & 150 & 100.0 \\
\hline
\end{tabular}


Information Literacy Competence and Skills among Faculty Members of Blde and Secab Engineering Colleges in Vijayapura

The respondents from the above table-4 shows regarding the visiting to library. Out of 150 to 150 they visit the library.

Table 5 Frequency of visit to library.

\begin{tabular}{|c|c|c|c|}
\hline Sl no & Frequency of visit to library & Frequency & Percent (\%) \\
\hline 1 & Almost Daily & 15 & $10.0 \%$ \\
\hline 2 & Once in Week & 48 & $32 \%$ \\
\hline 3 & Twice a Week & 56 & $37.33 \%$ \\
\hline 4 & Fortnightly & 12 & $8 \%$ \\
\hline 5 & Once a Month & 11 & $7.33 \%$ \\
\hline 6 & Occasionally & 4 & $2.66 \%$ \\
\hline & Total & 150 & $97.32 \%$ \\
\hline
\end{tabular}

The table 5 shows that majority of the faculty member $56(37.33 \%)$ visit the library twice a week, and there are 48(32\%) visit in once week, $15(10 \%)$ visit almost daily, $12(8 \%)$ visit fortnightly, $11(7.33 \%)$ once a month, and only few of them are $4(2.66 \%)$ visiting occasionally.it can be seen that all faculty member visiting the library but it is found that $10 \%$ are visiting daily.

Table 6 Purpose of library visit

\begin{tabular}{|c|c|c|c|}
\hline Sl no & Purpose & N & Percent (\%) \\
\hline 1 & To borrow and lending books & 150 & $100.0 \%$ \\
\hline 2 & To read the journal articles & 139 & $92.7 \%$ \\
\hline 3 & To read the newspapers and magazines & 150 & $100.0 \%$ \\
\hline 4 & For the reference & 130 & $86.67 \%$ \\
\hline 5 & Research purpose & 90 & $60 \%$ \\
\hline 6 & Browsing internet & 92 & $61.3 \%$ \\
\hline 7 & Update knowledge & 64 & $42.67 \%$ \\
\hline 8 & Project work & 98 & $65.33 \%$ \\
\hline
\end{tabular}

Above table reveals that out of 150 to $150(100 \%)$ respondents have visited library for 'to borrow and lending books, and like that 150 (100.0\%) 'To read the newspapers and magazines, while 139 (92.7\%) are visited to read the journal articles, 130 (86.67\%) said for references, 98(65.33\%) for the Project work, another 92 (61.3\%) for Browsing internet, 90 $(60 \%)$ for Research purpose followed by 64 (42.67\%) visiting for Update knowledge. It is conclude that the all the faculty member visit library for purpose of borrow and lending books and read newspaper and magazines and journal articles.

Table 7 Types of information needed

\begin{tabular}{|c|c|c|}
\hline Need of information & N & Percent (\%) \\
\hline Academic information & 150 & $100.0 \%$ \\
\hline Generalised information & 150 & $100.0 \%$ \\
\hline Health information & 31 & $20.7 \%$ \\
\hline Research information & 108 & $72.0 \%$ \\
\hline Statistical information & 52 & $34.66 .0 \%$ \\
\hline Current information & 71 & $47.33 \%$ \\
\hline Financial information & 90 & $60 \%$ \\
\hline
\end{tabular}


Fairojakhatun Pathan and Gavisiddappa Anandhalli

\begin{tabular}{|c|c|c|}
\hline Political information & 83 & $55.3 \%$ \\
\hline Information related Govt. programme and policy & 69 & $46.0 \%$ \\
\hline Environmental Information & 85 & $56.66 \%$ \\
\hline
\end{tabular}

The above table explains about what type of information needed the respondents 150 $(100 \%)$ needs 'Academic information, followed by the same $150(100 \%)$ General information, and 108 (72\%) Research information, 90(60\%) financial Information, $85(56.66 \%)$ related to Environmental Information, 83 (55.3\%) Political information, and 71 (47.33\%) Current information, 69(46.0\%) Information of Govt. programs and policy, 52 (34.66\%) Statistical information, 31(20.7\%) health information respectively.

Table 8 Access needed information

\begin{tabular}{|c|c|c|}
\hline Needed information & $\mathbf{N}$ & Percent (\%) \\
\hline Library & 150 & $100.0 \%$ \\
\hline Internet/Web & 150 & $100.0 \%$ \\
\hline Medias(TV,Radio,Newspaper & 41 & $27 \%$ \\
\hline
\end{tabular}

The above table reveals that out of 150 to $150(100 \%)$ are access the needed information through the Library, and same as $150(100 \%)$ needed information through the Internet/Web, only $41(27 \%)$ accessing information through the Medias (TV, Radio, Newspaper) respectively.

Table 9 Types of sources that you use to satisfy your information need

\begin{tabular}{|c|c|c|}
\hline Sources & Frequency N=150 & N \\
\hline Books & 150 & $100.0 \%$ \\
\hline Journals & 150 & $100.0 \%$ \\
\hline Back volume of periodical & 31 & $20.7 \%$ \\
\hline Reference sources & 116 & $77.3 \%$ \\
\hline Standard and specification & 150 & $100.0 \%$ \\
\hline Technical Reports & 41 & $27.3 \%$ \\
\hline Patents & 108 & $72.0 \%$ \\
\hline Government Publication & 83 & $55.3 \%$ \\
\hline E-Books & 150 & $100.0 \%$ \\
\hline E-Journals & 105 & $70.0 \%$ \\
\hline CD-ROM sources & 107 & $71.3 \%$ \\
\hline E-database & 140 & $93.3 \%$ \\
\hline
\end{tabular}

Above table shows the level of satisfaction of different types of information sources, that highest of the respondent fully satisfied 150 to $150(100 \%)$ Books, $150(100 \%)$ satisfy for journals available in library, $150(100 \%)$ satisfy for E-Books, and standard and specification 150 (100\%), the second most highest 140(93.3\%) satisfy for E-database, and 116 (77.3\%) satisfying Reference sources, 108 (72.0\%) satisfy for pate patents, 107 (71.3\%) CDROM sources 105(70.0\%) E-Journals and remaining 83\% (55.3\%) Government Publication, and very few of them $31(20.7 \%)$ satisfying Back volume of periodicals. 
Information Literacy Competence and Skills among Faculty Members of Blde and Secab Engineering Colleges in Vijayapura

Table 10 Use engineering E-database sources

\begin{tabular}{|c|c|c|c|c|c|c|c|c|}
\hline & Never & Rarely & $\begin{array}{c}\text { Somewhat } \\
\text { used }\end{array}$ & Used & $\begin{array}{c}\text { Highly } \\
\text { used }\end{array}$ & $\begin{array}{c}\text { Total } \\
\text { scores }\end{array}$ & Mean & Rank \\
\hline IEEE & 12 & 0 & 0 & 44 & 94 & 658 & 4.386 & 1 \\
Explore & 8 & 0 & 0 & 29.3 & 62.7 & & & \\
\hline \multirow{2}{*}{ INSPEC } & 12 & 0 & 11 & 87 & 40 & 593 & 3.953 & 3 \\
& 8 & 0 & 7.3 & 58 & 26.7 & & & \\
\hline \multirow{2}{*}{ Compendex } & 12 & 0 & 0 & 98 & 40 & 604 & 4.026 & 2 \\
\hline \multirow{2}{*}{ Pro Quest } & 8 & 0 & 0 & 65.3 & 26.7 & & & \\
& 12 & 19 & 22 & 97 & 0 & 504 & 3.36 & 4 \\
\hline \multirow{2}{*}{ NTIS } & 46 & 30 & 12 & 62 & 0 & 390 & 2.6 & 5 \\
& 30.7 & 20 & 8 & 41.3 & 0 & & & \\
\hline \multirow{2}{*}{ ASCE } & 46 & 30 & 52 & 22 & 0 & 350 & 2.333 & 6 \\
\hline \multirow{2}{*}{ ASCM } & 30.7 & 20 & 34.7 & 14.7 & 0 & & & \\
& 46 & 30 & 52 & 22 & 0 & 350 & 2.333 & 6 \\
\hline
\end{tabular}

The above table 10 shows uses E-database that distribution made rank wise $1^{\text {st }}$ rank it means highly used 94(62.7\%) given IEEE Explore, and $2^{\text {nd }}$ rank given to Compendex it means $98(65.3 \%)$ used, and $3^{\text {rd }}$ is given to INSPEC it mean $87(58 \%)$, and followed $4^{\text {th }}$ rank one given to ProQuest $97(64.7 \%)$ just used, and $5^{\text {th }}$ NTIS $62(41.3 \%)$, like that $6^{\text {th } \mathrm{r}}$ rank is given to ASCE, and ASCM that is $22(14.7 \%)$ uses E-database in engineering colleges respectively. 
Fairojakhatun Pathan and Gavisiddappa Anandhalli

Table 11 Identification of sources by the faculty members

\begin{tabular}{|c|c|c|c|c|}
\hline & Sources & Primary & Secondary & Tertiary \\
\hline \multirow[t]{2}{*}{1} & \multirow{2}{*}{ Patent } & 53 & 0 & 0 \\
\hline & & 35.33 & 0 & 0 \\
\hline \multirow[t]{2}{*}{2} & \multirow{2}{*}{ Book } & 0 & 89 & 0 \\
\hline & & 0 & 59.33 & 0 \\
\hline \multirow[t]{2}{*}{3} & \multirow{2}{*}{ Journals } & 67 & 0 & 0 \\
\hline & & 44.66 & 0 & 0 \\
\hline \multirow[t]{2}{*}{4} & \multirow{2}{*}{ Standard and specification } & 42 & 0 & 0 \\
\hline & & 28 & 0 & 0 \\
\hline \multirow[t]{2}{*}{5} & \multirow{2}{*}{ Dissertation and Thises } & 55 & 0 & 0 \\
\hline & & 36.66 & 0 & 0 \\
\hline \multirow[t]{2}{*}{6} & \multirow{2}{*}{ Dairies } & 12 & 0 & 0 \\
\hline & & 8 & 0 & 0 \\
\hline \multirow[t]{2}{*}{7} & \multirow{2}{*}{ Biblliography } & 0 & 0 & 23 \\
\hline & & 0 & 0 & 15.33 \\
\hline \multirow[t]{2}{*}{8} & \multirow{2}{*}{ Autobiography } & 18 & 0 & 0 \\
\hline & & 12 & 0 & 0 \\
\hline \multirow[t]{2}{*}{9} & Text book & 0 & 48 & 0 \\
\hline & & 0 & 32 & 0 \\
\hline \multirow[t]{2}{*}{10} & \multirow{2}{*}{ Handbook } & 0 & 37 & 0 \\
\hline & & 0 & 24.66 & 0 \\
\hline \multirow[t]{2}{*}{11} & \multirow{2}{*}{ Encyclopedia } & 0 & 39 & 0 \\
\hline & & 0 & 26 & 0 \\
\hline \multirow[t]{2}{*}{12} & \multirow{2}{*}{ Review article } & 0 & 41 & 0 \\
\hline & & 0 & 27.33 & 0 \\
\hline \multirow[t]{2}{*}{13} & \multirow{2}{*}{ Research paper } & 28 & 0 & 0 \\
\hline & & 18.66 & 0 & 0 \\
\hline \multirow[t]{2}{*}{14} & \multirow{2}{*}{ Manuscript } & 13 & 0 & 0 \\
\hline & & 8.66 & 0 & 0 \\
\hline
\end{tabular}

The above table 11 highlight that the respondent identifying a primary sources out of 150 respondents identify 53(35.33\%) patent, like that $67(44.66 \%)$ journal,42(28\%) standard and specification, 55(36.66\%) identified the Dissertation and Theses, like that 12(8\%) Dairies, 18(12\%) Autobiography, 28(18.66\%) Research paper, 13(8.66\%) Manuscript, same as the respondent identifying secondary sources like 89 (59.33\%) Books, like 48 (32\%) was identify Text Book, 37(24.66) Handbook, 39(26\%) Encyclopedia, 41(27.33\%) Review article, finally respondent identifying Tertiary sources only 23(15.33\%) was identify Bibliography. 
Information Literacy Competence and Skills among Faculty Members of Blde and Secab Engineering Colleges in Vijayapura

Table 12 Tools used for locating information

\begin{tabular}{|c|c|c|c|c|c|c|c|c|}
\hline $\begin{array}{c}\text { Locating } \\
\text { information }\end{array}$ & $\begin{array}{l}\text { Highly } \\
\text { used }\end{array}$ & Used & Somewhat & Rarely & Never & $\begin{array}{c}\text { Total } \\
\text { scores }\end{array}$ & Mean & Rank \\
\hline \multirow{2}{*}{$\begin{array}{c}\text { Library } \\
\text { catalogue }\end{array}$} & 93 & 57 & 0 & 0 & 0 & \multirow[t]{2}{*}{693} & \multirow[t]{2}{*}{4.62} & \multirow[t]{2}{*}{1} \\
\hline & 62 & 38 & 0 & 0 & 0 & & & \\
\hline \multirow[t]{2}{*}{ Bibliographies } & 2 & 2 & 7 & 139 & 0 & \multirow[t]{2}{*}{317} & \multirow[t]{2}{*}{2.113333} & \multirow[t]{2}{*}{4} \\
\hline & 1.34 & 1.34 & 4.67 & 92.67 & 0 & & & \\
\hline \multirow[t]{2}{*}{ Union catalogue } & 61 & 45 & 23 & 10 & 11 & \multirow[t]{2}{*}{585} & \multirow[t]{2}{*}{3.9} & \multirow[t]{2}{*}{2} \\
\hline & 40.67 & 30 & 15.34 & 6.67 & 7.34 & & & \\
\hline \multirow{2}{*}{$\begin{array}{l}\text { Abstract and } \\
\text { indexes }\end{array}$} & & 23 & 94 & 21 & 12 & \multirow[t]{2}{*}{428} & \multirow[t]{2}{*}{2.853333} & \multirow[t]{2}{*}{3} \\
\hline & 0 & 15.34 & 62.67 & 14 & 8 & & & \\
\hline \multirow{2}{*}{$\begin{array}{l}\text { OPAC (Online } \\
\text { public access } \\
\text { catalogue) }\end{array}$} & 0 & 0 & 32 & 84 & 34 & \multirow{2}{*}{298} & \multirow{2}{*}{1.986667} & \multirow{2}{*}{5} \\
\hline & 0 & 0 & 21.34 & 56 & 22.67 & & & \\
\hline
\end{tabular}

The above table shows Tools used for locating information that is distribution made rank wise $1^{\text {st }}$ rank given to Library catalogue it means highly used $93(62 . \%)$,and $2^{\text {nd }}$ given Union catalogue 61(40.67\%), and followed by $3^{\text {rd }}$ rank given to Abstract and indexes $94(62.67 \%)$ used, like that $4^{\text {th }}$ is given to Bibliographies $139(92.67 \%)$, and last $5^{\text {th }}$ rank given to OPAC (Online public access catalogue) 34 (22.67\%).

Table 13 Awareness about the library catalogue

\begin{tabular}{|c|c|c|}
\hline Opinion & N & Percent \\
\hline Yes & 150 & 100.0 \\
\hline No & 0 & 0 \\
\hline Total & 150 & 100.0 \\
\hline
\end{tabular}

The respondents from the above from table shows that awareness about library catalogue out of 150 to $150(100 \%)$ are found to be awareness about the library catalogue.

Table 14 The sources usually covered in the catalogue

\begin{tabular}{|c|c|c|}
\hline Sources & Frequency N=150 & $\mathbf{N}$ \\
\hline Government publication & 150 & 100.0 \\
\hline Videos & 93 & 62.00 \\
\hline CDs & 62 & 41.3 \\
\hline Books & 139 & 92.7 \\
\hline Article & 97 & 64.7 \\
\hline Journals & 97 & 64.7 \\
\hline Magazines Article & 141 & 94.00 \\
\hline
\end{tabular}


The above table explain that $150(100 \%)$ replied that the catalogue covered about the Government publication, and $141(94.00 \%)$ say about the Magazines Article, 139(92.7\%) catalogue covered books, 97(64.7) catalogue usually covered Journals, like that 97(64.7) covered about Article, whereas 93(62\%) said about Videos.

Table 15 Place where information is searched

\begin{tabular}{|c|c|c|}
\hline Information searched & $\mathbf{N = 1 5 0}$ & percent\% \\
\hline Library & 150 & 100.0 \\
\hline Internet/Web & 126 & 84.00 \\
\hline Medias (T.V, Radio, Newspaper) & 35 & 23.3 \\
\hline
\end{tabular}

Table-15 it revealed that all the respondent out of 150 to $150(100 \%)$ searching information Library for getting the required information, and $126(84.00 \%)$ is used to search information through the Internet/Web, whereas only $35(23 \%)$ search through channels of the Medias (T.V, Radio, Newspaper) respectively.

Table 16 Skill find a book in shelve in the library collection

\begin{tabular}{|c|c|c|}
\hline Skills & N & Percent (\%) \\
\hline By ISBN & 19 & $12.7 \%$ \\
\hline By Author & 150 & $100.0 \%$ \\
\hline By Title & 126 & $84.0 \%$ \\
\hline By call number & 61 & $40.7 \%$ \\
\hline I don't know & 35 & $23.3 \%$ \\
\hline
\end{tabular}

The above table 16 shows about the skill to find book in shelve the data provided by the respondent it is clear that $150(100.0 \%)$ have skill to find books by author, and $126(84.0 \%)$ they used skill by Title, $61(40.7 \%)$ by call number, whereas only few of them have skill about find a book on shelves by ISBN, 35 (23.3\%) they do not know anyone them.

Table 17 Search strategy used to get the information

\begin{tabular}{|c|c|c|}
\hline Search strategy & $\mathbf{N = 1 5 0}$ & Percent \\
\hline Manual card catalogue & 150 & $100.0 \%$ \\
\hline Browse through the shelves & 150 & $100.0 \%$ \\
\hline Consult Bibliographies & 68 & $45.3 \%$ \\
\hline Utilization of index and Abstract & 46 & $30.7 \%$ \\
\hline OPAC & 131 & $87.3 \%$ \\
\hline Website & 545 & $363.3 \%$ \\
\hline
\end{tabular}

Table 17 shows that search strategy used to get information majority of the respondent $545(363.3 \%)$ used Website, the second highest out 150 to $150(100.0 \%)$ respondent used 'Browse through the shelves, like that $150(100.0 \%)$ uses manual card catalogue, and $131(87.3 \%)$ OPAC is used as search strategy, and 68(45.3\%) consult bibliographies, whereas only $46(30.7 \%)$ utilization of index and abstract.

Table 18 Method used to search electronic resources

\begin{tabular}{|c|c|c|}
\hline Method of Search & N & Percent \\
\hline Through specific URL & 139 & $92.7 \%$ \\
\hline
\end{tabular}


Information Literacy Competence and Skills among Faculty Members of Blde and Secab Engineering Colleges in Vijayapura

\begin{tabular}{|c|c|c|}
\hline Through search engine like Google's Yahoo & 150 & $100.0 \%$ \\
\hline Through subject gateway/portals & 139 & $92.7 \%$ \\
\hline Total & 428 & $285.3 \%$ \\
\hline
\end{tabular}

The above table 18 revealed that majority 150 (100.0\%) respondent used the method of search electronic resources is through search engine like Google's Yahoo' and 139 (92.7\%) through specific URL, like that 139 (92.7\%) through subject gateway/portals respectively.

Table 19 Search strategy used to search information in search engine

\begin{tabular}{|c|c|c|}
\hline Search strategy in search engine & N & Percent \\
\hline Type the required statement is s each box & 202 & $134.7 \%$ \\
\hline Type the keyword in search box & 150 & $100.0 \%$ \\
\hline Type the keyword using Boolean operators & 115 & $76.7 \%$ \\
\hline Use wildcard/Truncations & 467 & $311.3 \%$ \\
\hline
\end{tabular}

The table 19 shows that respondent used the strategy to search the information 202(134.7\%) Type the required statement in search box and $150(100 \%)$ Type the keyword in search box, like that $115(76.7 \%)$ Type the keyword using Boolean operators, whereas highest respondent used the 467 (311.3\%) use wildcard/Truncation.

Table 20 Channels of information

\begin{tabular}{|c|c|c|}
\hline Channels & N & Percent (\%) \\
\hline Accessing online database & 139 & $92.7 \%$ \\
\hline Attending seminar, conference symposia etc. & 98 & $65.3 \%$ \\
\hline Personal visit to subject specialists & 118 & $78.7 \%$ \\
\hline Through telephone & 35 & $23.3 \%$ \\
\hline Through fax & 97 & $64.7 \%$ \\
\hline Through email & 106 & $70.7 \%$ \\
\hline
\end{tabular}

Table-20 reveals that majority of the respondent 139 (92.7\%) Accessing online database, like that $118(78.7 \%)$ Personal visit to subject specialists, $106(70.7 \%)$ access through the email, $98(65.3 \%)$ use to access the information attending seminar, conference symposia etc., 97 (64.7\%) Through fax, 35(23.3\%) Through telephone.

Table 21 Parameter for evaluated the information

\begin{tabular}{|c|c|c|}
\hline Parameter & N & Percent \\
\hline Accuracy & 150 & $100.0 \%$ \\
\hline Validity & 150 & $100.0 \%$ \\
\hline Usability & 108 & $72.0 \%$ \\
\hline Authority & 150 & $100.0 \%$ \\
\hline Timeliness & 140 & $93.3 \%$ \\
\hline Reliability & 140 & $93.3 \%$ \\
\hline Currency & 150 & $100.0 \%$ \\
\hline Objectivity & 150 & $100.0 \%$ \\
\hline Comprehensive accessibility & 150 & $100.0 \%$ \\
\hline
\end{tabular}

The above table 21 gives detail about the evaluation parameter of information that followed by the faculty of engineering colleges the majority of the respondent fallowed out of 
150 to $150(100 \%)$ accuracy, validity, authority, currency, objectivity, comprehensive accessibility, but the $140(93.3 \%)$ timeliness, reliability, only one of them parameter usability that is $108(72)$

Table 22. Evaluate information its authenticity

\begin{tabular}{|c|c|c|}
\hline Evaluation & N & Percent \\
\hline $\begin{array}{c}\text { To evaluate the information in term of currency authority and } \\
\text { appropriateness }\end{array}$ & 150 & $100.0 \%$ \\
\hline $\begin{array}{c}\text { To consult other sources to verify the information gathered } \\
\text { To evaluate the information available in internet }\end{array}$ & 109 & $72.7 \%$ \\
\hline Total & 322 & $214.7 \%$ \\
\hline
\end{tabular}

The table 22 is describes to evaluate information its authenticity. In this study, 150 respondent able to evaluate its authenticity $(100.0 \%)$ use to evaluate the information in term of currency authority and appropriateness, and 109 respondent able $(72.7 \%)$ consult other sources to verify the information gathered, 63(42.0\%) respondent able to evaluate the information available in internet".

Table 23 Problems and barriers while searching information

\begin{tabular}{|c|c|c|}
\hline Problems & N & Percent \\
\hline $\begin{array}{c}\text { Lack of knowledge about use of library catalogue } \\
\text { Lack of knowledge about arrangement of the books on shelves in } \\
\text { library }\end{array}$ & 104 & $69.3 \%$ \\
\hline Unfamiliarity with search method & 61 & $40.7 \%$ \\
\hline Loo much time consuming searching the information & 126 & $84.0 \%$ \\
\hline Lack of quality of information & 61 & $40.7 \%$ \\
\hline Slow access & 83 & $55.3 \%$ \\
\hline Difficulty to finding relevant information & 150 & $100 \%$ \\
\hline Lack of IT knowledge & 138 & $92.0 \%$ \\
\hline Lack of training in library & 116 & $77.3 \%$ \\
\hline
\end{tabular}

Table-23 shows the problems and barriers faced while searching the information. $150(100.0 \%)$ Difficulty to finding relevant information, and $138(92.0 \%)$ lack of IT knowledge, 126 respondents $(84.0 \%)$ report too much time consuming searching the information, 116 respondents $(77.3 \%)$ said Lack of training in library,104 respondents $(69.3 \%)$ report that lack of knowledge about use of library catalogue, while 93 respondent said(62\%) lack of knowledge about arrangement of the books on shelves in library,83 respondents $(55.3 \%)$ slow access, like that 61 respondents $(40.7 \%)$ report that unfamiliarity with search method, and lack of quality of information.

Table 24 Social issues around the use of information

\begin{tabular}{|c|c|c|c|c|c|}
\hline Statements & $\mathbf{A}$ & SA & NAND & D & SD \\
\hline \multirow{2}{*}{$\begin{array}{l}\text { I can identify and discuss the issue } \\
\text { related to privacy and security in both } \\
\text { print and electronic environments }\end{array}$} & 137 & 5 & 3 & 2 & 3 \\
\hline & 91.33 & 3.33 & 2 & 1.33 & 2 \\
\hline
\end{tabular}


Information Literacy Competence and Skills among Faculty Members of Blde and Secab Engineering Colleges in Vijayapura

\begin{tabular}{|c|c|c|c|c|c|}
\hline $\begin{array}{c}\text { I can identify and discuss issue } \\
\text { related to free information and paid } \\
\text { information }\end{array}$ & 75 & 3 & 63 & 5 & 4 \\
\cline { 2 - 6 } & 50 & 2 & 42 & 3.33 & 2.66 \\
\hline $\begin{array}{c}\text { I can identify and discuss issue } \\
\text { related to censorship and freedom of } \\
\text { speech }\end{array}$ & 44 & 3 & 76 & 23 & 4 \\
\cline { 2 - 6 } & 29.33 & 2 & 50.66 & 15.33 & 2.66 \\
\hline $\begin{array}{c}\text { I Have an understanding of } \\
\text { intellectual property, copyright and } \\
\text { fair use of copyright materials }\end{array}$ & 69 & 5 & 64 & 7 & 5 \\
\cline { 2 - 6 } & 46 & 3.33 & 42.66 & 4.66 & 3.33 \\
\hline
\end{tabular}

The above table explains that maximum respondents agree $137(91.33 \%)$ they can identify and discuss the issue related to privacy and security in both print and electronic environments, and followed by $75(50 \%)$ can identify and discuss issue related to free information and paid information, like that $69(46 \%)$ said that they have agree and understand of intellectual property, copyright and fair use of copyright materials, but $76(50.66 \%)$ not agree not disagree about the identify and discuss issue related to censorship and freedom of speech'

Table 25 Suggest the measures of important in information literacy skill and training

\begin{tabular}{|c|c|c|}
\hline Statements & $\mathbf{N}$ & Percent \\
\hline $\begin{array}{l}\text { The library should conduct periodical training programs for faculty member } \\
\text { and student on how to use the e-resources effectively and efficiently }\end{array}$ & 150 & $100.0 \%$ \\
\hline List of web resources on different subject useful for the faculty & 116 & $77.3 \%$ \\
\hline $\begin{array}{l}\text { Wi-Fi facility may be connected in library to get information quickly or } \\
\text { easy acces information }\end{array}$ & 146 & $97.3 \%$ \\
\hline $\begin{array}{l}\text { Awareness about the latest e-books, e-journal, full text articles, online } \\
\text { databases }\end{array}$ & 140 & $93.3 \%$ \\
\hline $\begin{array}{l}\text { More terminals should be installed in the library for easy access to } \\
\text { electronic resources for faculty \& students }\end{array}$ & 128 & $85.3 \%$ \\
\hline Total & 680 & $453.3 \%$ \\
\hline
\end{tabular}

Table 25 shows about suggestion and importance of information literacy skill for users of engineering colleges. In this study 150 respondent (100\%) suggest about "The library should conduct periodical training programed for faculty member and student on how to use the eresources effectively and efficiently, second 146 (97.3\%) Wi-Fi facility may be connected in library to get information quickly or easy access information, and 140 respondents $(93.3 \%)$ Awareness about the latest e-books, e-journal, full text articles, online databases, and 128 respondents $(85.3 \%$ ) More terminals should be installed in the library for easy access to electronic resources for faculty \& students, whereas 116 respondents $(77.3 \%)$ List of web resources on different subject useful for the faculty

\section{CONCLUSION}

The above study shows clearly information literacy is very important skill and important role in all fields. but specially in engineering field faculty members aware and updating their existing knowledge regarding accessing, locating uses different kind of tools and services uses various type sources and resources, search strategies, to know about the copyright, fair use intellectual property right, and social issue legal issues know they should have continues updates their knowledge and skills of current information specific and general fields.

\section{REFERENCES}


[1] Sanjakdar, Roukana (2013).Information Literacy Skills in Engineering Education: An Examination Of The Perspectives Of Faculty And Students Through A Case Study Conducted at Two Universities In Canada And The United Arab Emirates

[2] Klucevsek M. Kristin \& Brungard B.Alission (2016). Information literacy in science writing: how students find, identify, and use scientific literature. International Journal of ScienceEducation,2016,Vol.38,NO.17,25732595http://dx.doi.org/10.1080/09500693.2016 .1253120 .

[3] http://dx.doi.org/10.1080/09500693.2016.1253120.

[4] Information literacy learning model for engineering students. 5th WSEAS / IASME International Conference on ENGINEERING EDUCATION (EE'08), Heraklion, Greece, July 22-24, 2008.

[5] Rosmah Ali...etal (2010), Information literacy skill of engineering students. IJRRAS (3). Universiti Teknologi Malaysia International Campus, JalanSemarak 54100, Kuala Lumpur, Malaysia. 4Faculty of Forestry, Universiti Putra Malaysia, Serdang 43400, Selangor, Malaysia.

[6] https://researchspace.ukzn.ac.za/xmlui/bitstream/.../Omarsaib_Mousin_2015.pdf?

[7] https://spectrum.library.concordia.ca/977544/1/Sanjakdar_PhD_2013.pdf 